\title{
Pernikahan Dini; Ditinjau dari Aspek Psikologi
}

\author{
Surawan $^{1^{*}}$ \\ ${ }^{1}$ IAIN Palangkaraya, surawan@iain-palangkaraya.ac.id
}

\begin{abstract}
ABSTRAK
Pernikahan adalah sesuatu yang sakral, untuk itu perlu persiapan yang matang baik secara fisik, ekonomi dan psikologis. Untuk itu, tujuan penelitian ini adalah 1) faktor penyebab pernikahan dini, 2) dampak psikologi pernikahan dini dan 3) strategi menanggulangi dampak negatif pernikahan dini di Kecamatan Sanden Kabupaten Bantul tahun 2015-2018. Metode penelitian ini menggunakan deskriptif kualitatif yang dilaksanakan di Kecamatan Sanden Kabupaten Bantul tahun 2015-2018. Rentan penelitian dilaksanakan pada bulan Januari-Maret 2018 dengan melibatkan 10 responden pasangan pernikahan dini. Teknik pengumpulan data menggunakan wawancara, observasi dan dokumentas. Sedangkan analisis data menggunakan reduksi data, display dan verifikasi data atau kesimpulan. Hasil dari penelitian ini adalah 1) penyebab dari pernikahan dini adalah a) karena hamil terlebih dahulu dan b) faktor orang tua (ekonomi, pendidikan, pola asuh orang tua dan tingkat pemahaman agama orang tua). Sedangkan 2) dampak psikologi dari pernikahan dini adalah a) penyesuaian diri menjadi tergangu, b) harmonisasi keluarga, c) tingkat perceraian meningkat, d) hubungan sosial tergangu, d) pola asuh terhadap anak yang tidak kontinu, e) pendidikan yang terhenti dan f) ekonomi yang terpuruk. Untuk 3) strategi penanggulangan dampak negatif pernikahan dini adalah a) kerja sama antara keluarga dan penyuluh KUA dengan berkomunikasi secara intens dengan anak, selalu memberikan motivasi serta memberikan tauladan yang positif terhadap anak. b) pemerintah daerah (desa, puskesmas dan Penyuluh KUA) dengan cara memberikan nasehat atau penyuluhan tentang bahaya pergaulan dan reproduksi, pendataan orang-orang yang akan menikah, pengadaan sosialisasi ke desa, sekolah-sekolah dengan menggandeng KUA dan Puskesmas, serta memperketat undang-undang tentang pernikahan.

Kata kunci: pernikahan dini, dampak psikologis
\end{abstract}

\begin{abstract}
Marriage is something sacred, for that it needs careful preparation both physically, economically and psychologically. For this reason, the aims of this study are 1) the causes of early marriage, 2) the psychological impact of early marriage and 3) the strategy to overcome the negative effects of early marriage in Sanden District, Bantul Regency in 2015-2018. This research used qualitative descriptive method which was carried out in Sanden District, Bantul Regency in 2015-2018. The research was carried out in January-March 2018 involved 10 respondents' early marriage partners. Data collection techniques used interview, observation and documentation. Whereas data analysis used data reduction, display and data verification or conclusions. The results of this study were 1) the causes of early marriage were a) due to pregnancy before marriage and b) parental factors (economic, education, 200
\end{abstract}


parenting parents and the level of understanding of parents' religion). Whereas 2) the psychological impact of early marriage was a) disruption of adjustment, b) family harmonization, c) theincrease of divorce rate, d) disrupted of social relations, e) parenting towards children who were not continuous, f) education was stalled and g) economic downturn. For 3) strategies for overcoming the negative effects of early marriage were a) cooperation between families and religious affair office (KUA) counselors by communicating intensely with children, always provided motivation and provided positive role models for children. b) local governments (villages, health center and KUA instructors) by provided advice or counseling on the dangers of association and reproduction, data collection of people who were going to get married, provided socialization to villages, schools by cooperated with KUA and health center, and tightened the law on marriage.

Key words: early marriage, psychological impact

\section{Article history:}

Received : 30-7-2019

Revised : $1-8-2019$

Accepted : $27-1-2020$

Copyright (c) 2020 Surawan

\section{PENDAHULUAN}

Agama Islam adalah agama fitrah, dan manusia diciptakan Allah sesuai dengan fitrah. Oleh karena itu, Allah menyeru manusia untuk menghadapkan diri mereka ke agama agar tidak terjadi penyelewengan dan penyimpangan sehingga manusia tetap berjalan di atas fitrahnya. Salah satu seruan Allah yang bersifat fitrah tersebut adalah pernikahan. Pernikahan bagi masyarakat Indonesia merupakan peristiwa yang sakral,oleh karena itu masih tetap menjunjung tinggi nilai adat dan agama yang beraneka ragam. Hal ini semakin dipertegas dengan dikeluarkannya undang-undang tentang perkawinan (Rumekti \& Pinasti, 2016: 1-16).

Perkawinan adalah suatu ikatan kehidupan bersama pria dan perempuan yang dihalalkan Allah SWT, untuk mendapatkan kebahagiaan dan kesejahteraan serta anak dan keturunan yang shaleh dan shalehah. Pernikahan merupakan suatu yang sangat manusiawi, karena pernikahan sesungguhnya sesuai dengan fitrah manusia yang sejalan dengan Al-Qur'an dan sunah Nabi saw. Pengertian fitrah disini adalah sesungguhnya Allah telah membekali setiap diri manusia dengan hawa nafsu yang cenderung menyukai serta mencintai lawan jenisnya. Islam menilai dan 
menetapkan bahwa pernikahan adalah cara menyempurnakan pelaksanaan ajaran Agama (Aprianti dkk, 2018: 61-73).

Dalam kehidupan rumah tangga pasti tidak luput dari permasalahanpermasalahan. Salah satu penyebab utama permasalahan dalam rumah tangga adalah pasangan-pasangan yang belum dewasa. Faktor ketidak dewasaan ini lebih nyata terdapat dalam pernikahan usia remaja. Memang kedewasaan pribadi seseorang tidak tergantung pada umur, tetapi masa remaja adalah masa peralihan dari masa kanakkanak menuju masa dewasa. Pada masa remaja ini umumnya remaja belum memiliki kepribadian yang mantap dan kematangan berfikir. Perkawinan pada usia belia tidaklah menguntungkan bahkan jelas merepotkan kaum perempuan, dalam usia yang masih muda, remaja putri dituntut untuk mengurus rumah tangga, melayani suami, harus megandung dan melahirkan, kemudian merawat dan membesarkanya. Sedangkan mengandung dan melahirkan pada usia muda sangat beresiko tinggi bagi kesehatan, bagi ibu bisa menimbulkan kangker leher rahim.
Perkawinan yang masih muda juga banyak mengundang masalah yang tidak diharapkan dikarenakan segi psikologisnya belum matang khususnya bagi perempuan.

Menurut Basri dalam bukunya yang berjudul merawat cinta kasih mengatakan secara fisik biologis yang normal seorang pemuda atau pemudi telah mampu mendapatkan keturunan, tetapi dari segi psikologis remaja masih sangat hijau dan kurang mampu mengendalikan batera rumah tangga disamudra kehidupan. Berapa banyak keluarga dan perkawian terpaksa mengalami nasib yang kurang beruntung dan bahkan tidak berlangsung lama karena usia terlalu muda dari para pelakunya, baik salah satu atau keduanya (Basri, 2016: 76). Dan pernikahan yang terlalu muda juga bisa menyebabkan neuritis depresi karena mengalami proses kekecewaan yang berlarut-larut dan karena ada perasaan-perasaan tertekan yang berlebihan. Kematangan sosial-ekonomi dalam perkawinan sangat diperlukan karena merupakan penyangga dalam memutarkan roda keluarga sebagai akibat perkawinan. Pada umumnya umur yang masih muda belum 
mepunyai pegangan dalam hal sosial ekonomi. Padahal individu itu dituntut untuk memenuhi kebutuhan keluarga (Pohan, 2017: 424-435).

Dilihat dari segi psikologi perkembangan, dengan makin bertambahnya umur seseorang, di harapkan akan lebih masak, akan lebih matang lagi psikologisnya. Menurut Bimo walgito, menikah dalam usia muda memiliki dua dampak cukup berat yaitu, pertama dari segi fisik. Hal ini karena remaja itu belum kuat, tulang panggulnya masih terlalu kecil sehingga bisa membahayakan dalam proses persalinan. Sehingga bisa berakibat fatal bagi ibu yang melahirkan maupun anaknya. Oleh karena itu pemerintah mendorong perempuan jika ingin hamil sebaiknya pada usia 20-30 tahun.

Kedua, dari segi mental. Jika remaja menikah di usia yang masih muda, maka sesungguhnya emosi mereka belum stabil. Kestabilan emosi umumnya terjadi pada usia di atas 20 tahun, karena pada saat itulah orang mulai memasuki usia dewasa. Masa remaja, boleh di bilang baru berhenti pada usia 19 tahun dan sedangkan ketika seseoraang menikah pada usia 20-24 tahun, secara usia bisa disebut dewasa muda atau lead edolesen. Pada masa ini, biasanya mulai timbul transisi dari gejolak remaja ke masa dewasa yang lebih stabil (Walgito, 2015: 30). Sedangkan menurut Undang-undang Pernikahan Nomor 1 Tahun 1974, menyatakan usia ideal untuk menikah yaitu diusia 21 tahun, sedangkan pernikahan yang terjadi pada usia 16 tahun untuk anak perempuan dan 19 tahun untuk lakilaki. Sehingga ketika akan melaksanan pernikahan pasangan calon pengantin tersebut diharuskan memiliki surat ijin atau rekomendasi dari Pengadilan Agama Kabupaten Gunung Kidul.

Dari segi psikologi sosial maupun hukum Islam pernikahan dini dibagi menjadi dua kategori, pertama pernikahan dibawah umur asli yaitu pernikahan dini yang benar-benar murni dilaksanakan oleh kedua belah pihak untuk menghindarkan diri dari dosa tanpa adanya maksud semata-mata hanya untuk menutupi perbuatan zina yang telah dilakukan oleh kedua mempelai. Kedua, pernikahan dini palsu yaitu pernikahan dini yang pada hakikatnya dilakukan sebagai 
menutupi kesalahan-kesalahan mereka dalam hal ini orang tua juga ikut berpera serta (Ghifari, 2018: 20).

Namun jika dilihat dari segi psikologis usia remaja belum bisa dikatakan matang, karena pada usia remaja belum mempunyai kepribadian yang mantap dan masih labil, dan pada usia remaja pada umumnya belum mempunyai pegangan dalam hal sosial dan ekonomi. Remaja masih canggung dalam hidup berbaur dengan masyarakat luar, dan mereka belum mempunyai pekerjaan yang tetap dan kadang masih bergantung pada orang lain. Hal ini akan membuat runyam sebuah rumah tangga, sehingga akan menjadi bibit-bibit pertengkaran yang berakhir dengan perceraian (Dariyo, 2015: 105).

Ada beberapa faktor terjadinya pernikahan dini, yaitu: faktor pendidikan, faktor ekonomi, karena kebiasaan dan adat istiadat setempat, melanggengkan hubungan dan faktor telah melakukan hubungan biologis (married by exident) (Ahmadi, 2015). Pernikahan dini memberikan banyak problematika baik bagi pelaku maupun orang-orang yang ada di sekitarnya. Dampak negative dari pernikahan dini diantaranya adalah pendidikan, kependudukan dan kelangsungan rumah tangga. Menurut Walgito, perkawinan yang masih terlalu muda banyak mengundang masalah yang tidak diharapkan karena segi psikologisnya belum matang seperti cemas dan stress (Walgito, 2015: 20).

\section{II.METODE PENELITIAN}

\section{A. Jenis Penelitian}

Dalam hal ini peneliti menggunakan jenis penelitian deskriptif kualitatif. Penelitian kualitatif merupakan penelitian yang bermaksud untuk memahami fenomena tentang apa yang dialami oleh subyek penelitian misalnya perilaku, persepsi, motivasi, tindakan, dan lain-lain, secara holistik, dan dengan cara deskripsi dalam bentuk kata-kata dan bahasa, pada suatu konteks khusus yang alamiah dan dengan memanfaatkan berbagai metode alamiah (Moleong, 2015:6). Tempat penelitian atau lokasi penelitian dilaksanakan di masyarakat Kecamatan Girisubo Kabupaten Gunung Kidul dengan masa pernikahan tahun 2015-2018. Subjek dalam penelitian ini sebanyak 10 keluarga dari pernikahan dini 
dalam kurun masa pernikahan antara tahun 2015-2018.

\section{B. Teknik Pengumpulan Data}

Metode pengumpulan data dalam penelitian ini menggunakan observasi, wawancara dan dokumentasi. Observasi

\section{Analisis Data}

Teknik analisis data menggunakan reduksi, display dan verifikasi data atau kesimpulan

\section{HASIL DAN PEMBAHASAN}

\section{A. Faktor Penyebab Pernikahan Dini}

Setelah melakukan kajian yang mendalam, berikut adalah penyebab pernikahan dini yang terjadi di Kabupaten Gunung Kidul, yaitu:

1. Nikah karena Hamil (Married By Accident)

Dalam rangka memperjelas status anak yang dikandung, maka dilakukan pernikahan antar keduanya. Meskipun hal ini akan berdampak negatif bagi keduanya, terutama jika keduanya masih berstatus sebagai pelajar dan belum bekerja, sehingga pasangan pengantin baru ini akan rawan terjadi cekcok, yang berawal dari munculnya masalah-masalah kecil seperti bara api yang kena panas

sedikit akan terbakar. Kehamilan terjadi akibat melakukan hubungan seks sebelum menikah dengan pacarnya, karena permintaan pacar dan rangsangan dari tontonan pornografi. Mereka melakukan hubungan tersebut di rumah ketika sepi. Remaja melakukan hubungan seksual sebelum menikah salah satunya karena paparan pornografi. Dengan demikian, jika remaja cenderung senang terhadap pornografi akan timbul rangsanganrangsangan yang mengarah pada seks. Rangsangan ini mendorong remaja untuk melakukan hubungan seks pranikah yang pada akhirnya memberikan dampak kehamilan di luar perkawinan.

Berdasarkan keterangan dari KUA Girisubo bahwa penyebab pernikahan dini adalah pergaulan bebas dan ekonomi.

"Pernikahan dini di Girisubo kebanyakan penyebabnya adalah hamil terlebih dahulu. Dari tahun 2014-2017 sekitar 90\% karena hamil dan hanya 1 orang saja yang disebabkan karena faktor ekonomi".

Berdasarkan wawancara peneliti sebanyak $90 \%$ penyebab pernikahan dini di Kecamatan Girisubo adalah hamil (married by accident). 
Sedangkan $10 \%$ atau 1 keluarga pendampingan yang ekstra terhadap menikah karena faktor ekonomi. Hal pergaulan anak muda di era modern. ini menunjukan perlunya

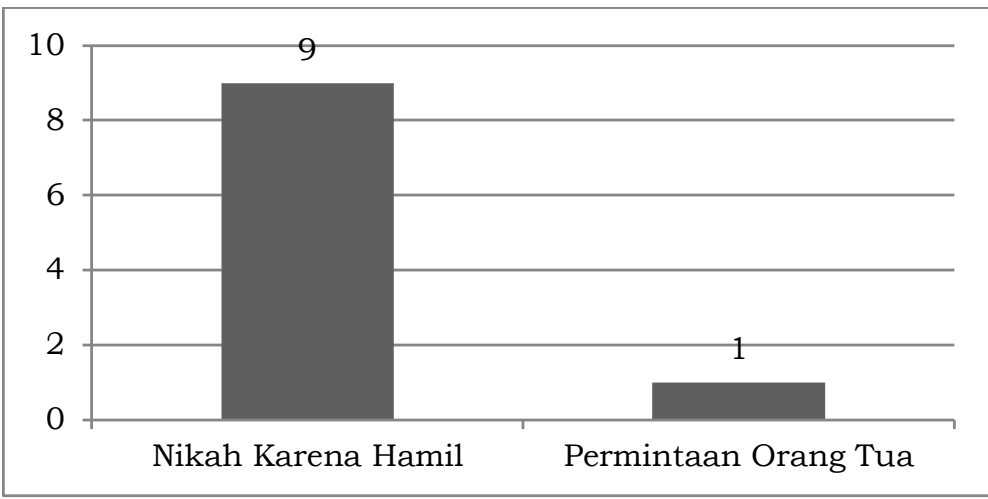

Grafik 1. Pernikahan Dini Kecamatan Girisubo Tahun 2015-2018

2. Kondisi Orang Tua

Anak-anak akan mencontoh perilaku orang tuanya. Oleh karena itu dalam membentuk karakter anak orang tua hendaknya dapat memahami tahapan-tahapan pendidikan karakter. Maka jika disadari orang tua yang ideal akan mempengaruhi pembentukan karakter dari anak-anaknya. Akan tetapi sulitlah kiranya untuk menyebut orang tua ideal itu karena derasnya pengaruh sosial budaya. Sosial budaya dipengaruhi oleh modernitas. Di era dahulu sosial budaya kita membentuk masyarakat bersahaja, di masa sekarang membentuk masyarakat madya, dan tentu saja di era yang akan datang akan membentuk masyarakat modern yang kesemuanya mempengaruhi kepribadian masingmasing.

Ada beberapa alasan orang tua menikahkan anaknya di usia yang yang belum matang (dini), yaitu kondisi ekonomi orang tua serba kekurangan sehingga mengakibatkan orang tua hanya focus tentang mencari nafkah tanpa memperhatikan pergaulan anakanaknya, pendidikan orang tua yang rendah mengakibatkan rendah pula tentang pengetahuan bahaya pergaulan bebas, dan tingkat pemahaman agama orang tua menyebabkan tidak terlalu memperhatikan akhlak atau tingkah laku anak. 


\section{B. Dampak Pernikahan Dini Ditinjau dari Aspek Psikologi}

Pernikahan yang terlalu muda juga bisa menyebabkan neuritisdepresi karena mengalami proses kekecewaan yang berlarutlarut dankarena ada perasaanperasaan tertekan yang berlebihan. Kematangansosial-ekonomi dalam perkawinan sangat diperlukan karena merupakanpenyangga dalam memutarkan roda keluarga sebagai akibat perkawinan.Pada umumnya umur yang masih muda belum mepunyai pegangan dalamhal sosial ekonomi (Walgito, 2014: 32). Berdasarkan hasil wawancara dan observasi yang peneliti lakukan, ada beberapa dampak psikologi dari pernikahan dini yang terjadi di masyarakat Kecamatan Bantul, yaitu:

1. Penyesuaian Diri yang Terganggu

Manusia dituntut untuk menyesuaikan diridengan lingkungan sosial, kejiwaan, danlingkungan alam sekitarnya. Kehidupan itusendiri secara alamiah juga mendorong manusia untuk terus-menerus menyesuaikandiri. Penyesuaian diri artinya suatu proses dinamika yang bertujuan untuk mengubah perilaku individu agar terjadi hubungan yang lebih sesuai antara diri individu dengan lingkungannya. Dengan batasan tersebut dapat diberikan batasan bahwa kemampuan manusia sanggup untuk membuat hubunganhubungan yang menyenangkan antara manusia dengan lingkungaya.

Cemas dan depresi akan menghampiri bagi mereka yang menikah di usia dini. Rasa malu dan menyesal terhadap apa yang terjadi, apalagi penyebab pernikahan dini adalah hamil di luar nikah. Perbuatan tersebut akan mejadi aib bagi keluarga besar yang sulit dihilangkan. Berdasarkan wawancara dengan mayoritas subjek mereka mengatakan menyesal menikah di usia muda.

$$
\text { Aprilia Christanti pada }
$$
wawancara 18 Maret 2018 mengatakan "Aku sangat menyesal. Kenapa dulu melakukannya. Sehingga akhirnya aku hamil. Dulu aku tidak mendengarkan omongan orang tua. Aku merasa depresi dengan kondisi seperti ini. Pernah ada rencana untuk menggugurkan kandungan, namun was-was kalau nanti terjadi dengan saya." 


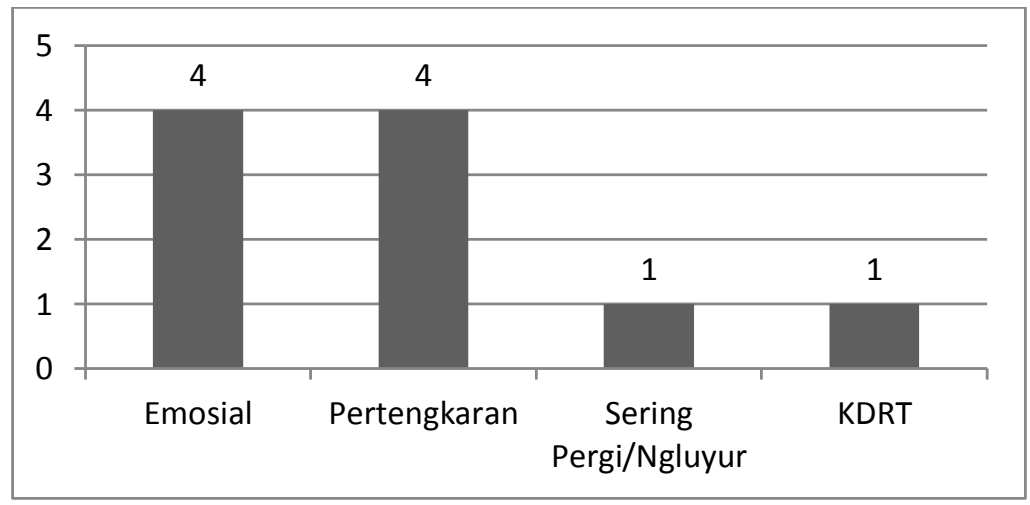

Grafik 2. Kondisi Psikologi Pernikahan Dini

Berdasarkan grafik 2 di atas dapat dijelaskan bahwa hasil wawancara dengan 10 pasangan (20 orang) hasil pernikahan dini adalah sebanyak 4 orang mengalami frustasi, 5 orang mengalami konflik batin, 6 orang mengalami kecemasan, 2 orang menyesali diri dan 3 orang mengalami depresi.

\section{Sering Terjadi Pertengkaran}

Perkawinan yang masih terlalu mudabanyak mengundang masalah yang tidakdiharapkan karena segi psikologisnyabelum matang seperti cemas danstress. Berdasarkan hasil penelusuran peneliti telah terjadi perceraian dari subjek pernikahan dini. Perceraian terjadi karena suami pergi dan tidak bertanggung jawab, sesuai dengan hasil interview dengan Ida Wijayanti (12 Maret 2018) berikut ini:

"Kami sering bertengkar pak, baik tentang anak, tempat tinggal dan masalah duit. Masih susah ngontrol emosi”.

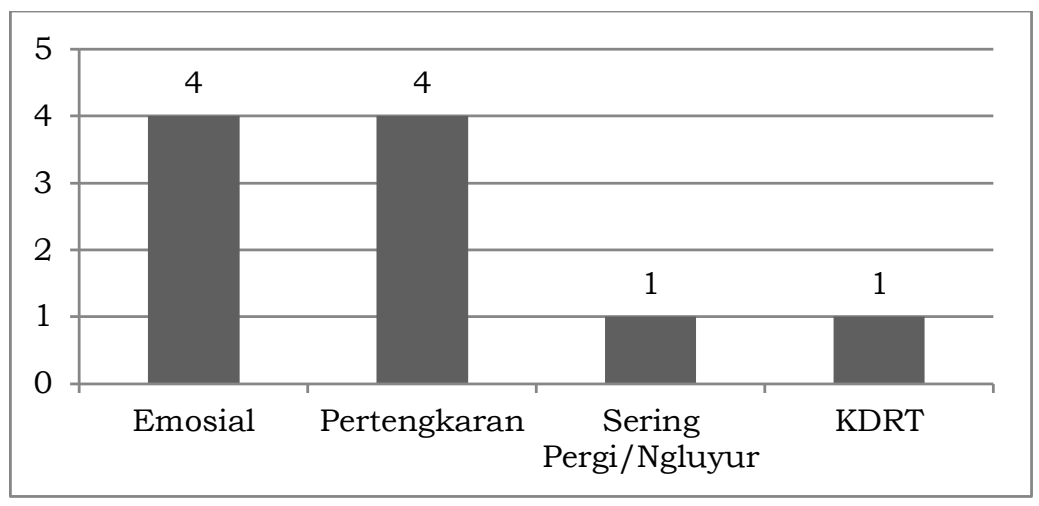

Grafik 3. Harmonisasi Keluarga Pernikahan Dini

Berdasarkan grafik 3 di atas, dari 10 pasangan pernikahan dini sebanyak 4 orang masih sering emosi 208 yang meluap-luap, sebanyak 4 orang sering terjadi pertengkaran dalam rumah tangga, sebanyak 1 orang 
masih sering pergi dengan temanteman dan 1 orang pernah terjadi kekerasan dalam rumah tangga.

\section{Perceraian yang Selalu Membayangi \\ Dalam sebuah rumah tangga} sulit digambarkan tidak terjadinya percekcokan. Akan tetapi percekcokan itu sendiri beragam bentuknya; ada yang ibarat seni dan irama dalam kehidupan rumah tangga yang tidak mengurangi keharmonisan dan ada pula yang menjerumuskan kepada kemelut yang berkepanjangan yang dapat terjadi putusnya perkawinan. Diantara sebab-sebab perceraian adalah krisis ekonomi, kesenjangan pikiran dan mental, mengungkap aib rumah tangga, dorongan keluarga kedua belah pihak, perbedaan status sosial dan ketidakharmonisan rumah tangga.Dari kasus pernikahan dini yang terjadi di Kabupaten Gunung Kiduldalam kurun 2014-2017 sudah ada kasus percerian dari pernikahan dini sebanyak 1 orang. Berdasarkan interview dengan Rahma Dani (5 Maret 2018) alasan perceraian adalah karena suami tidak tanggung jawab. "saya bercerai dengan suami, karena suami tidak tanggung jawab pak. Lha pripun, suami sering minum-minuman keras, suka mukulin saya dan tidak bekerja. Lalu apa yang tak harapkan dengan lakilaki seperti itu. Alhamdullah setelah bercerai, saya menikah lagi dengan seseorang yang insya Allah baik dan bisa menuntun ke jalan yang diridhoi oleh Allah swt".

\section{Hubungan Sosial}

Manusia adalah makhluk sosial yang tidak dapat lepas dari manusia yang lain. Dimanapun dan kapanpun dia berada akan selalu tergantung pada orang lain. Untuk itulah manusia selalu berhu-bungan atau berinteraksi dengan manusia lain, baik secara individu, baik secara individu atau secara kelompok. Dalam proses interaksi tersebut tentu ada hubungan dengan yang sifatnya timbal balik.

Joko Winarno dalam wawancara (8 Maret 2018) mengatakan "Ketika ada acara di kampung seperti kumpulan biasanya diwakili bapak atau mertua. Saya males kalau kumpul dengan bapak-bapak. Kadang juga malu karena yang sudah terjadi. Bahkan kumpulan 
muda-mudi saja saya sekarang sudah jarang datang, karena malu".

\section{Pola Asuh Anak yang Tidak Jelas}

Orang tua sangat berpengaruh besar dalam kehidupan anak diantaranya, pembentukan kepribadian anak, memilih agama yang benar sesuai ajaran al-Qur'an, kelangsungan hidup anak, dan masa depan anak kelak. Orang tua bertanggung jawab pada anak di dunia dan di akhirat kelak. Orangtua adalah guru dan orang terdekat bagi anak yang harus menjadi panutan. Karenanya, orangtua dituntut untuk bekerja keras untuk memberikan contoh dalam memelihara ketaatan serta ketekunan dalam beribadah dan beramal salih. Oleh karena itu orang tua harus menanamkan akidah pada anak sejak dini.

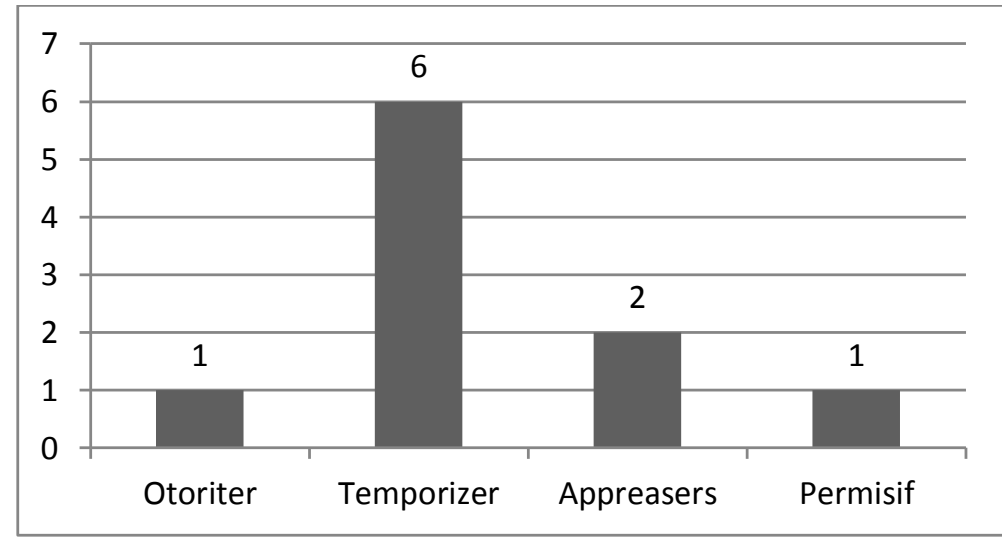

Grafik 4. Pola Asuh terhadap Anak

Berdasarkan grafikan grafik 4 di atas pola asuh yang dilakukan orang tua muda adalah sebanyak 1 orang menerapkan gaya pola asuh otoriter, sebanyak 6 orang menerapkan pola asuh temporizer (pola asuh yang tidak konsisten), sebanyak 2 orang melakukan pola asuh appeasers (pola asuh khawatir) daan 1 orang menerapkan pola asuh permisif (bebas). Namun pada kenyataannya banyak dari subjek yang menitipkan anaknya ke orang tua mereka (neneknya).
6. Ekonomi dan Beban Pikiran

Pernikahan usia muda terjadi karena keadaan keluarga yang hidup digaris kemiskinan, untuk meringankan beban orang tuanya maka anak wanitanya dinikahkan dengan orang yang lebih mampu. Masalah ekonomi sangat penting dalam sebuah rumah tangga, karena ketika orang sudah menikah secara kewajiban mereka akan menanggung segala hal terkait kehidupan ke depan. Dengan usia yang masih 
belia, namun harus menanggung beban yang besar tentu mengakibatkan kondisi ekonomi subjek pernikahan dini termasuk memprihatinkan.

"Untuk masalah ekonomi kami masih sulit. Untuk kebutuhan sehari-hari kami banyak dibantu oleh orang tua atau mertua. Kalau penghasilan setiap bulan tidak tentu, menangis ketika anak minta dibelikan sesuatu (mainan atau makanan kecil), sedangkan ketika mau membelikan saya tidak punya uang," papar Ida Wijayanti (12 Maret 2018).

Berikut ini adalah grafik yang diperoleh berdasarkan wawancara dengan subjek penelitian adalah sebagai berikut:

bahkan kadang tidak ada pemasukan sama sekali. Saya hanya ikut

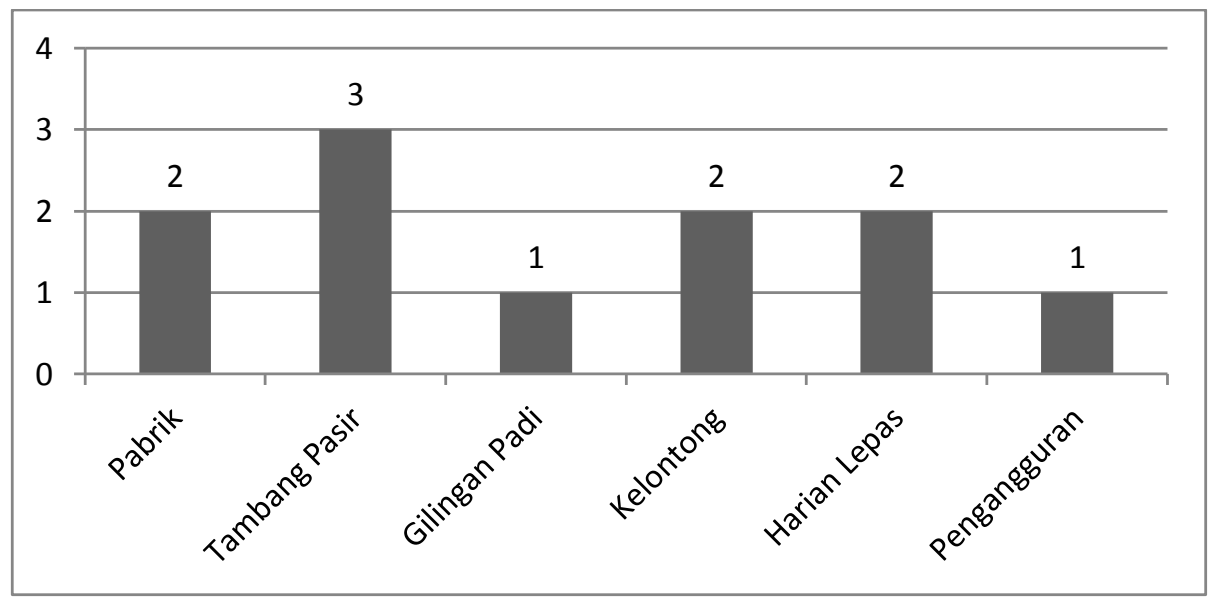

Grafik 5. Pekerjaan Subjek Pernikahan Dini

Berdasarkan grafik 5 di atas dapat dijelaskan bahwa 2 orang bekerja di buruh pabrik, 2 orang bekerja buruh harian lepas dan 2 orang bekerja serabutan. Sebanyak 3 orang bekerja sebagai buruh tambang pasir, sedangkan 1 orang usaha gilingan padi, 2 orang usaha kelontong dan 1 orang masih menganggur. Bagi subjek yang menganggur semua kebutuhan masih dipenuhi oleh orang tua atau mertua.

Dengan jenis pekerjaan di atas, maka untuk memenuhi kebutuhan sehari-hari menjadi kurang. Hal ini menambah depresi da kondisi rumah tangga mejadi kacau. Tekanan demi tekanan di alami oleh perlaku pernikahan dini. Hal ini sesuai dengan hasil interview dengan subjek Wulan Puji Astuti (3 Maret 2018), diantaranya hasilnya adalah: 
"Untuk masalah ekonomi kami sangat susah pak. Jangankan untuk beli susu, untuk beli beras saja tidak mampu. Gaji suami tidak tentu. Sehingga kalau susu habis kalau tidak minta orang tua ya diberi uang mertua. Aku sangat sedih sekali. Kadang mikir bagaimana ke depannya hidup kami. Yang bisa aku lakukan hanya menangis menyesali apa yang telah dilakukan dulu.

Sedangkan berdasarkan interview dengan para subjek ratarata penghasilan setiap bulan seperti grafik berikut ini:

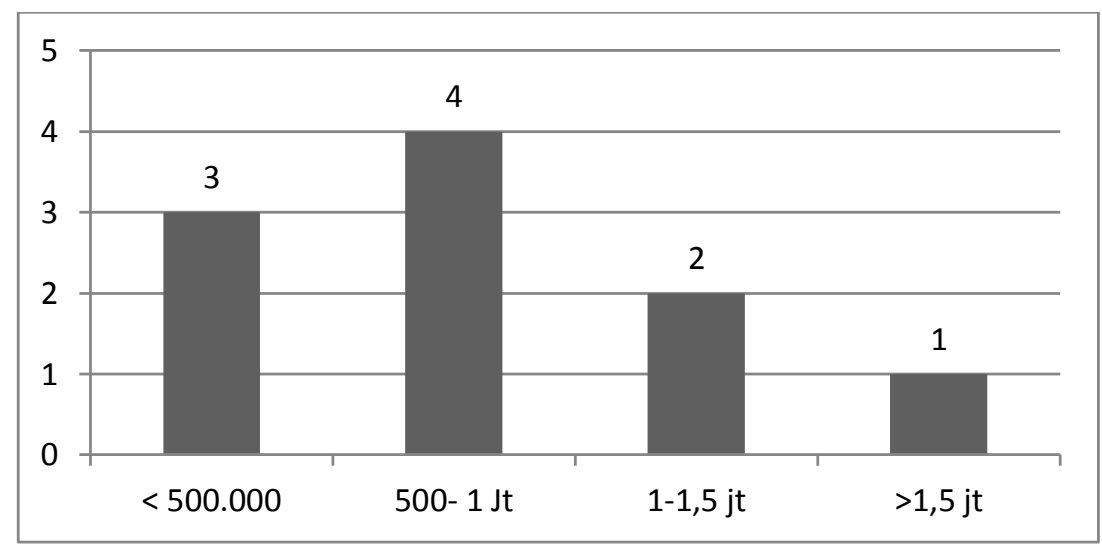

Grafik 6. Penghasilan Rata-rata Subjek Pernikahan Dini

Berdasarkan grafik 6 di atas, dapat dilihat sebanyak 3 orang ratarata penghasilan di bawah $\mathrm{Rp}$. 500.000, sedangkan 4 orang ratarata penghasilan sebulan berkisar antara Rp. 500.000 sampai dengan 1.000.000, sebanyak 2 orang berkisar Rp. 1.000.000 sampai 1.500.000 dan sebanyak 1 orang berpenghasilan di atas $\mathrm{Rp}$. 1.500.000.

7. Pendidikan Terhenti

Dari sisi pendidikan subjek penelitian terhenti dari melanjutkan pendidikan. Ada beberapa subjek yang berkeinginan melanjutkan melalui kejar paket, namun karena waktu dan rata-rata masih merawat anak sehingga niatannya mereka belum terealisasi. Hal tersebut disimpulkan berdasarkan wawancara dengan subjek Yunita Ryan Hidayah (10 Maret 2018).

Adapun

penyebaran pendidikannya adalah sebagai berikut: 


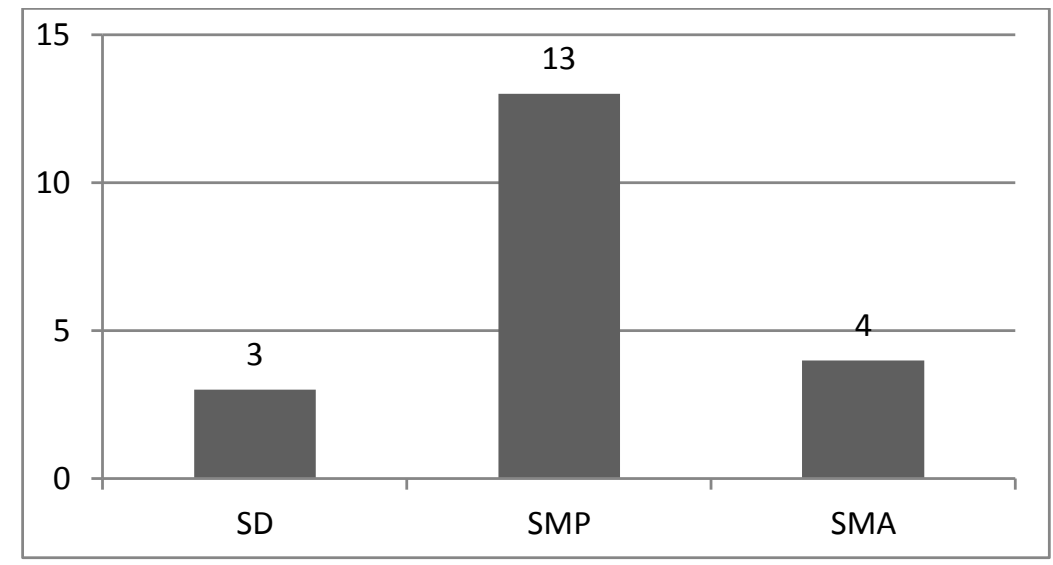

Grafik 7. Data Pendidikan Pernikahan Dini

Berdasarkan grafik 7 di atas dapat dilihat bahwa sebanyak 3 orang hanya lulus SD, sedangkan yang sempat mengenyam pendidikan SMP sebanyak 13 dan tingkat SMA sebanyak 4 orang. Peneliti kemudian mewawancarai salah satu subjek bernama Dina Septiana Wulandari (11 Maret 2018). Tentang keberlanjutan sekolah, kemudian dijawab:

'Ya sedih lah, kecewa. Aku kaya nyesal gitu lho pak.Kan temen-temen masih sekolahkan jadi iri gitu hlo. Coba dulu saya tidak hanya nuruti nafsu, pasti aku masih sekolah seperti teman-temanku. Sedangkan saya mau lanjut sudah mikir anak. Tapi untuk mencari pekerjaan sekerang harus punya pendidikan minimal SMA."

\section{Strategi Menghadapi Dampak Negatif Pernikahan Dini}

Angka pernikahan di usia muda setiap tahun terus mengalami peningkatan sehingga diperlukan upaya untuk menekan tingginya angka pernikahan usia muda. Untuk itu diperlukan langkah yang konkret dari semua stakehorders baik dari masyarakat maupun pemerintah. Beberapa langkah yang dapat dilakukan antara lain:

1. Pembinaan oleh Keluarga dan Penyuluh Agama

Keluarga adalah tempat pertama kali anak belajar mengenal aturan yang berlaku di lingkungan keluarga dan masyarakat. Orang tua bertugas sebagai pengasuh, pembimbing, pemelihara, dan sebagai pendidik terhadap anak-anaknya. Orang tua adalah pihak yang sering kali bersinggungan dengan seorang anak dalam kehidupan sehari-hari (Silalahi, 2017: 72). 
Keluargadanpenyuluh agama KUA Kecamatan Girisubo telah melakukan kerja sama dengan baik guna mencegah munculnya dampak negatif pasca pernikahan dini. Ada beberapa tahapan yang telah dilakukan oleh keluarga dan penyuluh agama dalam mencegah terjadinya dampak negatif dari pernikahan dini, yaitu:

a. Komunikasi

Orang tua sudah berusaha membimbing, menasehati dan menunjukkan dampak negatif yang bisa terjadi pada pernikahan usia dini kepada anak-anak mereka bahwa pernikahan usia dini itu sangat rawan terjadi perceraian, tidak pandai merawat anak, sulit mencari perkerjaan. Komunikasi yang terjadi dalam keluarga ini diungkapkan ketika Peneliti berkunjung kerumah bapak Wajirin, ayah dari Yunita Riyan Hidayah (21 Maret 2018) yang masih tinggal serumah.

"Nggih sampun kulo kandani pak anak kulo, yen nikah usia muda niku resikone gedhe, dereng siap cekel gawe kangge nyukupi butuh, dereng becus momong anak, gampang muntap sing ujung-ujunge kosreking kluargo. Nggih kulo kandani kudu sabar nekonten masalah kluwargo, mboten sithik-sithik pegat". Sudah pernah saya nasehati pak anak saya, kalau menikah usia diniitu sangat beresiko, belum siap bekerja untuk memenuhi kebutuhan, belum pandai mengurus anak, mudah emosi yang berujung pertengkaran keluarga. Juga sudah saya nasehati untuk senantiasa sabar apa bila ada persoalan keluarga jangan mudah mengucapkan kata cerai.

Pada kasus pasangan nikah usia dini yang lain, Sri Lestari ibu dari pasangan Joko Winarno dengan Aprilia Kartika Dewi juga senantiasa melakukan komunikasi dengan baik. Komunikasi yang terjadi dalam keluarga ini diungkapkan ketika Peneliti berkunjung ke rumah ibu Sri Lestari (21 Maret 2018).

"Mas Joko sudah sering kami minta untuk bersabar menghadapi Tika, lebih banyak ngalah karena sudah lebih dewasa".

Penyuluh Agama Islam KUA Kecamatan Girisubo juga telah melaksanakan perannya dengan baik pada persoalan ini, melalui program Bimbingan Caten yaitu bimbingan calon manten. Bimbingan caten ini diadakan sebagai salah satu bentuk pelayanan yang diberikan KUA 
kepada seluruh pasangan calon manten. Khusus pasangan caten usia dini penyuluh agama bekerja sama dengan penghulu KUA dalam hal menginformasikan data-data caten, kemudian penyuluh agama memberikan bimbingan secara khusus, dengan materi yang mendalam untuk pencegahan prefentif terhadap dampak yang lebih luas dari pernikahan pasangan usia dini tersebut. Bentuk lain yang dilaksanakan oleh Penyuluh Agama adalah melakukan kunjungan ke rumah pasangan nikah usia dini. Kunjungan ini dilakukan secara berkala untuk memantau perkembangan keluarganya, persoalan-persoalan yang muncul, dan solusi-solusi yang bisa ditempuh.

b. Motivasi

Motivasi orang tua terhadap anaknya yakni pasangan nikah usia dini sudah dilakukan, walaupun pada akhirnya orang tua hanya menyerahkan semua pada anaknya karena para orang tua menganggap anak mereka sudah bisa menentukan mana yang baik dan mana yang buruk bagi anak mereka. Keluarga juga sudah memotifasi untuk meneruskan jenjang pendidikan, hal ini diungkapkan ketika Peneliti berkunjung ke rumah bapak Wajirin, ayah dari Yunita Riyan Hidayah yang masih tinggal serumah.

"Kulonggih pun surungpak, nek purun nggih le sekolah diteruske minimal SMA, kuloken pados nggen sinau paket $C$ niko kajenge saget disambi.". Sudah saya motifasi pak, kalau mau sekolahnya diteruskan minimal jenjang SMA, saya suruh mencari pendidikan kejar paket $\mathrm{C}$ agar bisa dilakukan sambil lalu.

Motivasi juga sudah diberikan orang tua kepada pasangan nikah usia dini dalam soal pekerjaan, bahkan bimbingan dan pendampingan juga dilakukan. Bimbingan dan pendampingan ini diungkapkan ketika Peneliti berkunjung ke rumah Bapak Wajirin, ayah dari Yunita Riyan Hidayah (21 Maret 2018) yang masih tinggal serumah.

"Sing kakungnggih pun kuloarahke, rasah isen nyambut gawe. Sak gawean-gaweane nggih pun kulo ajak ten pasar bantu kulo sadean wedus". Yang laki-laki juga sudah saya bimbing, tidak usah merasa malu untuk memulai kerja. Pekerjaan seadanya juga sudah saya 
ajak ke Pasar membatu saya jualan kambing pak.

\section{c. Pentauladanan}

Orang tua telah memberikan pentauladaan kepada anak puteri mereka salah satunya dengan menceritakan kepada anak puteri mereka bahwa mereka dulu tidak dibolehkan oleh orang tua mereka menikah usia dini karena sudah banyak contohnya orang yang menikah usia dini itu sering mengalami perceraian. Sedangkan model pembinaan yang dilakukan oleh KUA Girisubo kepada keluarga yang menikah karena usia dini dengan melakukan bimbingan atau pembinaan khusus.

2. Pemerintah Daerah (Desa dan KUA Girisubo)

Dengan banyaknya pernikahan usia diniakan berpengaruh pada pendidikan mereka, yang ujungujungnya bagi anakusia dini belum mendapatkan pengalaman dan pengetahuan maupunskill yang cukup untuk mendapatkan pekerjaan. Pemerintah Kecamatan Gunung Kidul, Puskesmas, Desa dan KUA Girisubo memang belum maksimal bekerja sama dalam membuat program, melakukan berbagai kegiatan untuk mengatasi dampak negatif pernikahan dini. Program dan kegiatan yang telah dilaksanakan yaitu:

a. Tahap Dinasehati

Tahap awal yang dilakukan pemerintah di Kecamatan Girisubo untuk menangani pernikahan dini dengan penasehatan. Penasehatan dilakukan oleh Pegawai Pencatat Pernikahan Nikah KUA Kecamatan Girisubo atau oleh Penghulu pada saat ada masyarakat yang mendaftar pernikahan tetapi dari persyaratan terdapat umur yang tidak sesuai dengan Undang-undang perkawinan di Indonesia. Apabila, karena bukan alasan yang urgent sebaiknya rencana pernikahan diundur sampai usia kedua mempelai cukup. Namun bila karena kekhususan (perempuan hamil) maka pernikahan bisa dilakukan dengan syarat mendapat surat dispensasi dari pengadilan Agama Kabupaten Gunung Kidul.

b. Tahap Pendataan

Data kasus pernikahan dini yang terjadi di wilayah Kecamatan Girisubo sudah tercatat di KUA Girisubo dengan baik, namun data ini baru sebatas kasus yang pelaksanaan pernikahan berada di wilayah Girisubo. Pendataan ini dilakukan pada pemerintahan kepala 
desa yang baru sehingga baru berjalan kurang lebih 1 tahun. Dari hasil pendataan tersebut pemerintah Desa di Kecamatan Girisubo menemukan beberapa anak yang seharusnya masih usia sekolah tetapi memilih menikah dan ada pula penduduk yang menikah tetapi akad nikahnya di luar Girisubo. Hal ini diungkapkan dalam wawancara dengan Lurah Jepitu (16 Maret 2018).

\section{c. Tahap Sosialisasi}

Kegiatan ini sebagai bentuk pencegahan preventif terjadinya kasus pernikahan dini agar tidak semakin meningkat jumlahnya. Mengatasi pernikahan dini di desadesa dengan sosialisasi ke masyarakat dengan cara pada saat ada kegiatan kemasyarakatan misalnya peringatan maulid nabi, gotong royong, posyandu dan lainlain, pada saat sambutan kepala desa dengan memberikan motivasi kepada orang tua untuk melanjutkan pendidikan ke yang lebih tinggi paling tidak sampai lulus SMA/MA dengan begitu anak-anak yang ingin melakukan pernikahan sudah mencukupi umur dan sesuai dengan undang-undang perkawinan sehingga tidak adanya pelanggaran terhadap undang-undang. Selain itu juga mensosialisasi efek negatif dari pernikahan dini kepada para siswa, baik terhadap masa depan pelaku maupun anak kedepannya.

Selain itu pemerintah juga sering bekerja sama dengan sekolah SMA/SMK yang ada di Girisubo dengan cara melakukan sosialisasi tentang bahaya pernikahan dini. Serta selalu menanamkan motivasi untuk belajar dengan rajin dan menghindari pergaulan yang bebas.
d. Perketat Undang-undang Pernikahan

Di Kecamatan Girisubo sebenarnya untuk masyarakat sudah mulai takut melangsungkan pernikahan dini karena pada saat ini aturan-aturan mengenai pernikahan sudah diperketat oleh pemerintah daerah, pemerintah desa maupun Kantor Urusan Agama. Hal tersebut terjadi karena masyarakat tidak ingin menempuh prosedur yang sulit hingga harus ke pengadilan Kabupaten Gunung Kidul.

\section{KESIMPULAN}

Dari hasil kajian yang telah dilakukan oleh peneliti, maka penelitian ini menyimpulkan adalah penyebab dari pernikahan dini di 
kecamatan Girisubo Kabupaten Daftar Pustaka

Gunung Kidul adalah karena hamil diluar nikah (MBA) sebesar 90\% dan kondisi orang tua sebanyak 10\%. Sedangkan dampak psikologi dari pernikahan dini adalah pendidikan dan ekonomi, hubungan sosial, penyesuaian diri, harmonisasi keluarga serta pola asuh anak dan perceraian. Untuk startegi dari pemerintah dalam rangka menanggulangi pernikahan dini adalah pertama, Pembinaan dan pendampingan oleh Keluarga dan penyuluh KUA dengan cara 1) berkomunikasi secara intens dengan anak; 2) selalu memberikan motivasi; 3) memberikan tauladan yang positif terhadap anak. Kedua, Pemerintah (Desa dan Penyuluh KUA) dengan cara 1) memberikan nasehat atau penyuluhan tentang bahaya pergaulan dan penyuluhan tentang kesehatan reproduksi; 2) pendataan orang-orang yang akan menikah; 3) mengadakan sosialisasi ke Desa, sekolah-sekolah dengan menggandeng KUA dan Puskesmas; 4) memperketat undang-undang tentang pernikahan.

Aprianti dkk. 2018. Fenomena Pernikahan Dini Membuat Orang Tua dan Remaja Tidak Takut Mengalami Kehamilan Tidak Diinginkan”. Jurnal Promosi Kesehatan Indonesia Vol. 13, No. 1.

Basro, Hasan. 2016. Merawat Cinta Kasih. Yogyakarta: Pustaka Pelajar.

Dariyo, Agus. 2015. Psikologi Perkembangan Dewasa Muda. Bandung: UPI.

Moleong, Lexy J. 2015. Metodologi Penelitian Kualitatif. Bandung: Remaja Rosda karya.

Rumekti, Martyan Mita V \& Pinasti, Indah Sri. 2016. "Peran Pemerintah Daerah (Desa) dalam Menangani Maraknya Fenomena Pernikahan Dini di Desa Plosokerep Kabupaten Indramayu" dalam Jurnal Pendidikan Sosiologi.

Pohan, Nazli Halawani. 2017. Faktor Yang Berhubungan Dengan Pernikahan Usia Dini Terhadap Remaja Putri. Jurnal Endurance Vol. 2, No. 3.

Silalahi, Uber. 2017. Metode Penelitian Sosial. Jakarta: Refika Aditama.

\begin{tabular}{lr}
\multicolumn{3}{r}{ Walgito, Bimo. 2015. Bimbingan } \\
dan Konseling & Perkawinan. \\
Yogyakarta: Yayasan & Penerbitan \\
Fakultas Psikologi UGM. &
\end{tabular}

